\title{
Stipular colleters in Psychotria nuda (Cham. \& Schltdl.) Wawra (Rubiaceae): micromorphology, anatomy and cristals microanalysis
}

\author{
Emílio de Castro Miguel ${ }^{1}$, Daniel Gomes de Moraes ${ }^{1}$ and Maura Da Cunha ${ }^{1}$
}

Recebido em 29/07/2008. Aceito em 18/02/2009

\begin{abstract}
RESUMO - (Coléteres Estipulares em Psychotria nuda (Cham. \& Schltdl.) Wawra (Rubiaceae): micromorfologia, anatomia e microanálise dos cristais). Coléteres são estruturas secretoras, com função protetora, que podem ocorrer em diferentes órgãos e em diversas famílias de Angiospermae. Esse trabalho teve como objetivo descrever a anatomia e micromorfologia dos coléteres estipulares presentes em Psychotria nuda (Cham. \& Schltdl.) Wawra bem como analisar a estrutura e composição dos cristais do eixo central da estrutura em questão. O material foi coletado na Reserva Biológica de Tinguá e processado de acordo com técnicas básicas de microscopia óptica e eletrônica de varredura. Os coléteres de P. nuda são do tipo lacrimiforme, constituídos por um eixo central alongado, formado por parênquima fundamental, circundado por um estrato epidérmico em paliçada responsável pela secreção mucilaginosa. Cristais do tipo ráfide foram observados no eixo central dos coléteres. Através de microanálise de raio-X foi possível mostrar a presença predominante de cálcio nessas estruturas.

Palavras-chave: cristais de oxalato de cálcio, coléteres, estrutura secretora, Rubiaceae
\end{abstract}

ABSTRACT - (Stipular colleters in Psychotria nuda (Cham. \& Schltdl.) Wawra (Rubiaceae): micromorphology, anatomy and crystal microanalysis). Colleters are secretory structures, with a protective function, that occur in different organs and in many Angiospermae families. The aim of this work was to describe the anatomy and micromorphology of colleters present in Psychotria nuda (Cham. \& Schltdl.) Wawra as well as analyze the structure and composition of crystals from the central axis of the structure under study. The material was collected at the Tinguá Biological Reserve and processed according to usual techniques for light and scanning electron microscopy. The colleters are of the lachrymiform type, with an elongated central axis, formed by fundamental parenchyma, sheathed by a palisade layer, responsible for the secretion. Raphid crystals were observed in the central axis of the colleters. By X-ray microanalysis it was possible to show calcium predominance in these structures.

Key words: Calcium crystals, colleters, secretory structure, Rubiaceae

\section{Introduction}

Psychotria L. is a pantropical genus in the tribe Psychotrieae (Robbrecht 1988). Psychotria nuda (Cham. \& Schltdl.) Wawra is a widely distributed shrub that can be 1 to 5 meters tall and is commonly called sonhos-de-ouro (golden dreams) (EMBRAPA 1994). This species is found throughout the Atlantic Forest along the eastern coast of Brazil. Even though colleters have been cited for some species of Psychotria (Whitmoyer \& Horner 1970; Da Cunha \& Vieira 1993/97) they have never been described for Psychotria nuda.

Colleters are secretory structures comprised of an elongated central axis formed by fundamental parenchyma that is surrounded by an epidermal palisade layer (Da Cunha \& Vieira 1993/97) made of secretory cells (Thomas 1991). The function of colleters is still under debate but it is believed that they protect the shoot apex and the lateral buds by a physical or chemical mechanism. This type of structure has been described under various names (Ramayya \& Bahadur 1968; Van Hove \& Kagoyre 1974; Dave \& Patel 1975; Curtis \& Lersten 1980), making it complicated to morphologically classify.

According to Thomas (1991), colleters are known to occur on different plant parts, such as the stipules and parts of the flower, in members of 60 angiosperm families, including Rubiaceae, Loganiaceae, and Apocynaceae. A revision of the Turneraceae showed that the colleters of different species within this group are present on different plant parts (González 1998). In the Rubiaceae colleters are intimately associated with the stipules but can also be present on the adaxial surface or margin of the leaves, or with trichomes on the calyx (Thomas 1991).
The number of colleters and how they are arranged can vary: they can be numerous or rare, cover more or less of the central portion of the stipules and/or the calyx, or they can be located at the margin or arranged in one or more rows at the base of the stipules. Klein et al. (2004) observed that the colleters of Simira pikia are distributed in a line at the base of the stipule, while the colleters of $S$. glaziovii form two triangles at the base of the stipule. Miguel et al. (2006) observed that the colleters of three species of Bathysa are distributed at the base of the stipules.

Various classifications have been used to name the different morphological types of colleters. Lersten (1974b) classified the colleters as standard and brushlike. Simões et al. (2006) lists the colleters in the Apocynaceae as laminar, standard, and sessile. Paiva \& Machado (2006a) observed that the colleters of Hymenea are elongate and clavate, and covered by an additional layer of cells. Miguel et al. (2006) observed that Bathysa nicholsonii has the standard type of colleters. González (1998) used additional terminology to classify colleters.

Calcium crystals accumulate in aquatic and terrestrial plants and are often deposited in the form of raphide bundles of calcium oxalate (Franceschi \& Nakata 2005). These crystals can protect the bark of a plant from insects (Hudgins et al. 2003), act as a defense against invertebrate (Korth et al. 2006) and vertebrate herbivory (Ward et al. 1997), and can also make the oxalate unavailable to plant cells.

The goal of this work was to describe the anatomy and the micromorphology of the colleters of Psychotria nuda.

\footnotetext{
Setor de Biologia Vegetal, Laboratório de Biologia Celular e Tecidual, Centro de Biociência e Biotecnologia - Universidade Estadual do Norte Fluminense Darcy Ribeiro. Campos dos Goytacazes/RJ, Brasil

E-mail para correspondência: maurauenf@gmail.br
} 


\section{Material and methods}

\section{Plant material}

The apices of the stems of adult individuals of Psychotria nuda were collected, at the Reserva Biológica de Tinguá, including the stipules and the shoot apex of each plant. The stipules were removed from the apex using forceps and a scalpel.

\section{Light microscopy}

Fragments of the base of each stipule, including the colleters, were fixed for two hours in a solution of water containing $2.5 \%$ glutaraldehyde and $4.0 \%$ formaldehyde diluted in a $0.05 \mathrm{M}$ sodium cacodylate buffer, at ca. 7.2 $\mathrm{pH}$, at room temperature. The fragments were washed for 45 minutes using the same buffer. They were post-fixed for one-hour, in the dark, in a solution of water containing $1.0 \%$ osmium tetroxide diluted in a $0.05 \mathrm{M}$ sodium cacodylate buffer, at ca. $7.2 \mathrm{pH}$, at room temperature. After washing the fragments three times for 45 minutes each, using the same buffer, the fragments were submitted three times for dehydration in an ascending cetone series $(50 \%, 70 \%, 90 \%$, $100 \%[3 \mathrm{X}]$ ); using a one-hour incubation period for each step. The fragments were then infiltrated with epoxy resin (Epon Polibed). The polymerization of the resin was made at $60{ }^{\circ} \mathrm{C}$. Sections approximately $1 \mu \mathrm{m}$ thick were made using an ultramicrotome with a glass blade (REICHERT ULTRACUT-S $\left.{ }^{\circledR}\right)$. Toluidine blue $(1.0 \%)$ was used to stain the sections, and permanent slides were mounted with Entellan ${ }^{\circledR}$. Observations were made using an Axioplan ZEISS (Oberkohen, Germany) light microscope, coupled with a Hamamatsu C3077 digital camera and the software Analysis $^{\circledR}$ - LINK/ISIS/ZEISS (Oxford, UK).

To observe the presence and the continuity of the cuticle, the colleters were mounted on slides in the dark and exposed to a water solution containing $0.01 \%$ Auramine O. After 15 minutes of exposure the sections were covered with a cover slide and taken to the light microscope. Stained sections were observed under a fluorescent microscope (excitation filter 470 to $490 \mathrm{~nm}$, and emission filter 515 to $565 \mathrm{~nm}$ ). Sections not exposed to $0.01 \%$ Auramine $\mathrm{O}$ were used as the control (Barros \& Miguens 1998).

\section{Scanning electron microscopy (SEM)}

For the SEM analysis, the material was treated, as described above, up to the step of dehydration. After dehydration the samples were subjected to $\mathrm{CO}_{2}$ critical point drying using a CPD-030 BAL-TEC (Liechtenstein). The stipule fragments and stem apices were mounted on stubs using carbon double-sided adhesive tape (3M) and carbon adhesive, and coated with $20 \mathrm{~nm}$ of gold using a sputter coater (SCD-050 BAL-TEC-Liechtenstein). The fragments were examined with a Zeiss (DSM 962) scanning electron microscope operating at $25 \mathrm{kV}$.
The qualitative analysis was performed by detecting $\mathrm{X}$-ray energy that was dispersed from stipule fragments when using the SEM. In order to analyze the chemical elements present in the oxalate crystals, fresh stipules were immersed in liquid nitrogen for 20 minutes and then fractured. Fragments of the fractured stipules were mounted on stubs using carbon adhesive tape (3M) and liquid carbon adhesive, and coated with carbon (using a XCD-010 BAL-TEC, Liechtenstien). The qualitative analysis and the creation of the distribution map of the elements detected were performed using the same SEM, which was coupled to a silicium/lithium X-ray detector (OXFORD Microanalysis Group - Oxford, UK), with 138 eV (1024 channels) nominal resolution, operating under standard conditions (voltage speed $25 \mathrm{KeV}$ (SE); working distance of $25 \mathrm{~mm}$; capturing microanalysis time of 300 seconds with a Be window). Results were analyzed using the software LINK-ISIS (OXFORD Microanalysis Group - Oxford, UK).

\section{Results and discussion}

Psychotria nuda has stipules at the apex of the stem that are approximately $1 \mathrm{~cm}$ long (Fig. 1). None of the apices analyzed had signs of herbivorous damage, and the stipules were covered with a secretion that is produced by the colleters (Fig. 2). Colleters were observed on the adaxial surface of the stipules. These were comprised of a central axis of parenchyma surrounded by an epidermal palisade layer (Fig. 3 and 4). Trichomes were observed on the stipules next to the colleters (Figs. 3 and 4).

Photosynthesis can occur in the stipules but the main function of these organs is to protect the development of young leaves (Fahn 1990). The results seen in our work corroborate with this conclusion. The morphology and size of the stipules apparently do not affect their ability to protect (Miguel et al. 2006). In P. nuda the secretion is viscid and becomes vitreous when dry, indicating that these organs and the secretion physically protect the shoot apex by preventing access to it. Miguel et al. (2006) showed that the secretion produced by the colleters of $B$. nicholsonii (Rubiaceae) has antifungal properties.

In general, the colleters are lacryform, cilyndric with a narrow base (Fig.5), sometimes with a tapering apex, and are attached basally to the leaf primordia (Fig. 6 and 7), next to trichomes. Colleters between the leaf primordia and the stipule were observed embedded in their own secretion (Fig.7). It was noted that the external periclinal walls of the epidermal cells are smooth (Fig. 8).

There are various terms used to classify colleter morphology. The first classification was created by Lersten (1974a); however, the best morphological term proposed for this type of structure is lacryform, which is based on external morphology and follows the classification by González (1998). 

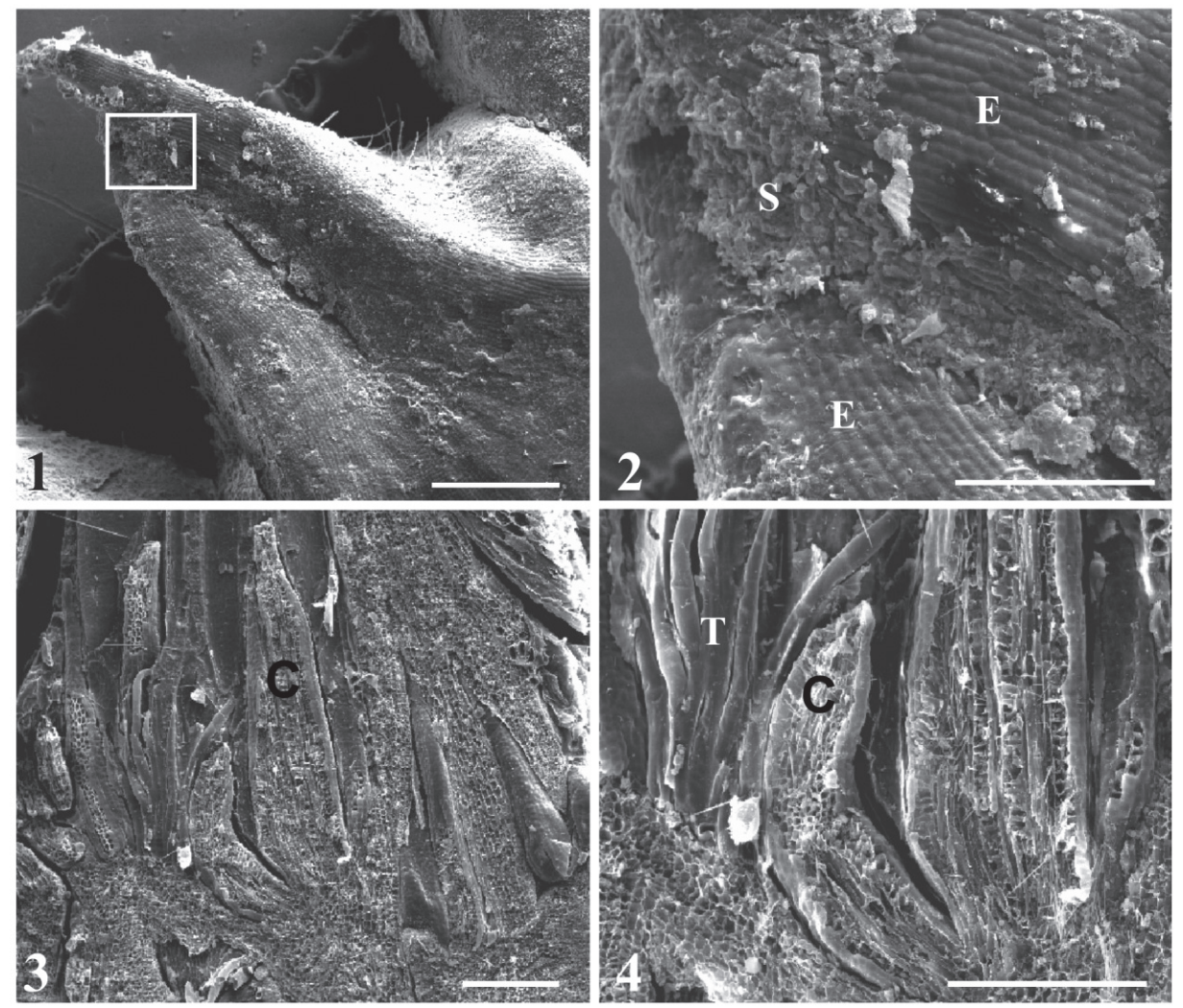

Figures 1-4. SEM of the shoot apex of $P$. nuda. 1. Stipules; 2. Close-up (square) showing the secretion (S) sealing the pair of stipules (E); 3. Longitudinal section of a stipule showing the colleters (C) and the trichomes (T); 4. Transversal section of the colleters and trichomes. Bars: $1-500 \mu \mathrm{m} ; 2,3$ and $4-200 \mu \mathrm{m}$.
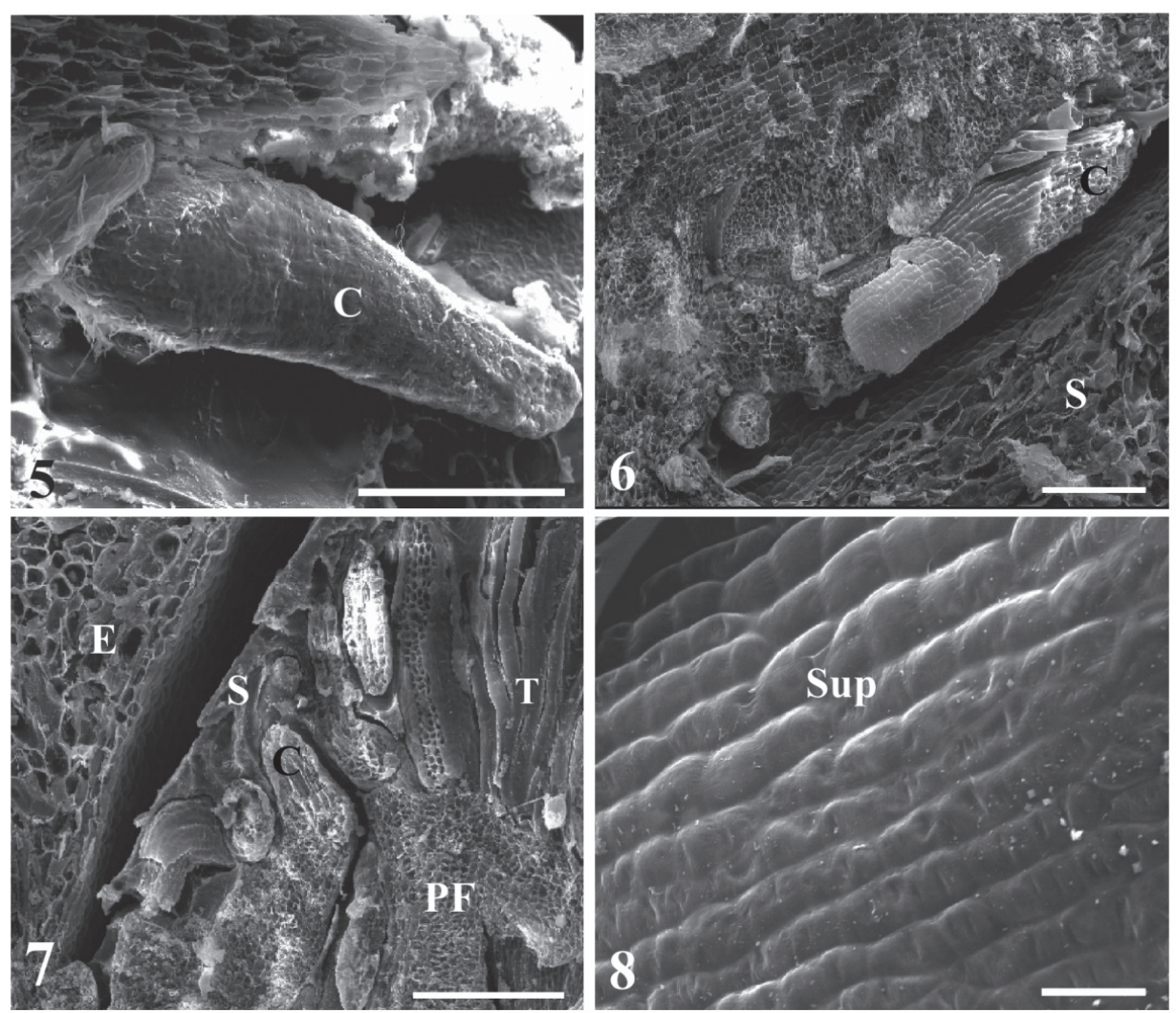

Figures 5-8. SEM of the shoot apex of P. nuda. 5. Colleter; 6 and 7. Longitudinal section of the stipule showing the colleters (C) covered by the secretion (S), on the leaf primordia (PF) next to trichomes (T); stipule (E); 8. Colleter surface. Bars: 5, 6 and 7 - $200 \mu \mathrm{m} ; 8$ - $20 \mu \mathrm{m}$. 
Observation of transversal sections, using light microscopy, revealed that the stem apex had colleters between the leaf primordia and outside of them (Fig. 9). These structures had never been noted on the adaxial surface of the leaf primordia in Rubiaceae. The transversal sections of the colleters also showed that these structures have a central axis formed by fundamental parenchyma that is surrounded by an epidermal palisade layer (Fig.10). The unisseriate palisade layer has a dense cytoplasm (Fig.11) with a thin cuticle, which was revealed by Auramine O (Fig. 12).

Morphological characteristics of the colleters, such as the constriction of the base, and anatomical characteristics, such as the vascularization of the central axis, are shared by other species in the Rubiaceae, for example, species of Bathysa (Miguel et al. 2006), Pavetta, Neorosea and Tricalysia (Lersten 1974a), Simira (Klein et al. 2006), and also taxa of other families, such as Mandevilla in the Apocynaceae (Appezzato-da-Gloria \& Estelita 2000). These characteristics do not seem to be diagnostic to the Rubiaceae, but can contribute to the classification of the family at the generic level (Lersten 1975; Da Cunha 2005).

According to Paiva and Machado (2006b), the colleters of Caryocar brasiliense have dense cytoplasm and a subcuticular gap that is formed by the dislocation of the cuticle from the cell wall. At a certain point the cuticle tears and the secretion is released. Miguel et al. (2006) and Klein et al. (2004) observed that the continuity of the cuticle and the absence of a subcuticular gap, as noted in P. nuda, are characteristics that appear to be conserved in the Rubiaceae.

Numerous raphide bundles and styloid crystals were observed between the shoot apex (Fig.13) and the stipule (Fig.14). Only raphide bundles were observed in the parenchyma of the central axis (Fig.15).

The qualitative analysis of the chemical elements that constitutes the crystals revealed a predominance of calcium (Fig.16). The map of the distribution of calcium shown in Speed Map ${ }^{\circledR}$ (Fig.17) coincided with the location of crystals (Fig.18).

The presence and the function of the calcium crystals in the colleters are debatable (Thomas 1991). However, this is the first description of raphide bundles in the central axis of a lacryform colleter. Based on the diversity and the spatial distribution of the crystals, there are numerous hypotheses for their function, including calcium regulation, protection, and detoxification (Franceschi \& Nakata 2005).

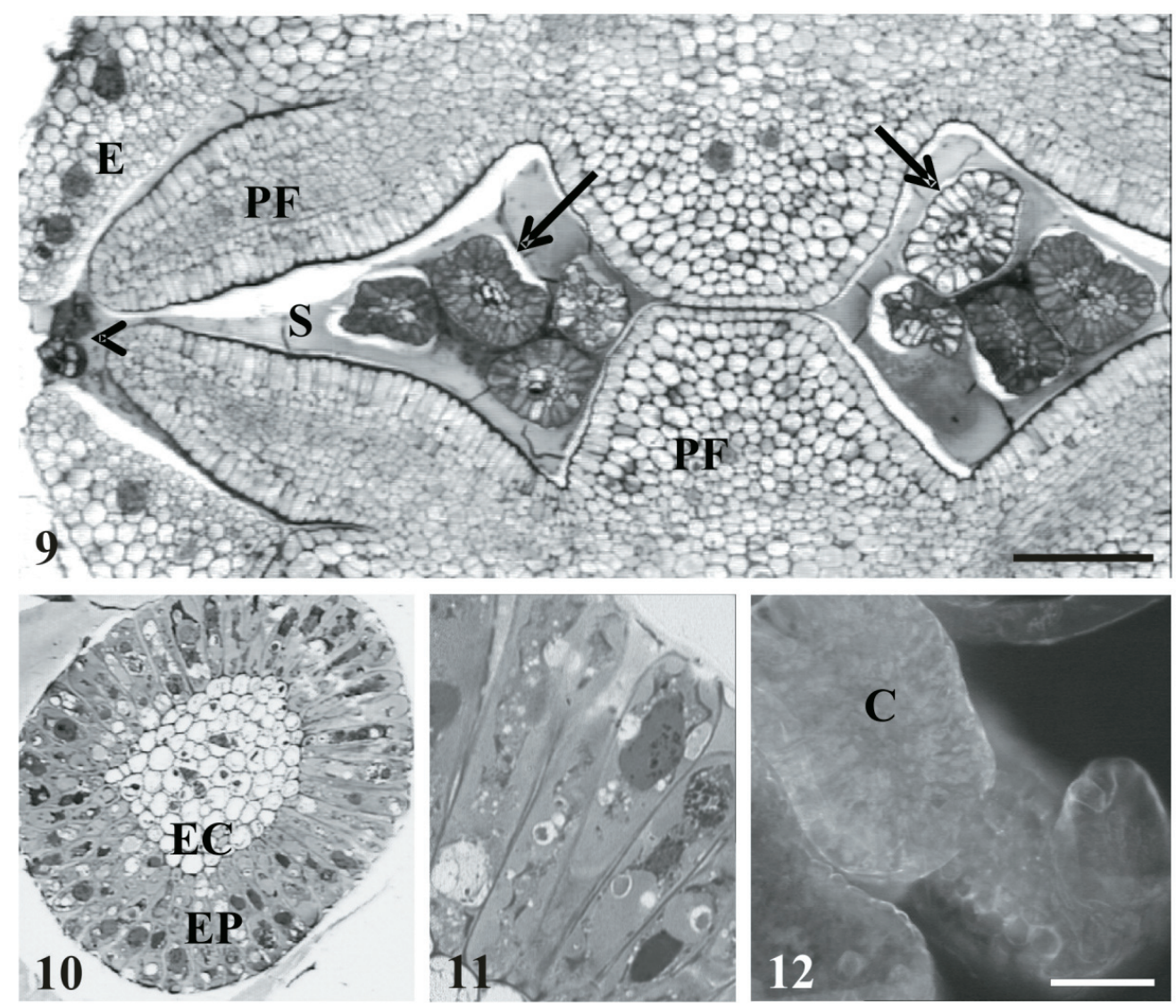

Figures 9-12. Light microscopy of the shoot apex and colleters of $P$. nuda. 9-11. Samples stained with toluidine blue. 12. Free-hand section stained with Auramine O. 9. Transversal section of the apex of the stem showing the presence of colleters between the leaf primordia (arrow), next to the stipule (arrowhead); 10. Transversal section of a colleter showing the central axis (EC) and the secretory epidermal palisade (EP); 11. Close up of the secretory epidermis; 12 . Auramine O stain showing the presence of a thin cuticle highlighted by fluorescence: leaf primordia (PF); stipule (E); secretion (S). Bars: 9 - $500 \mu \mathrm{m} ; 10$ and 12 - $50 \mu \mathrm{m} ; 11$ - $100 \mu \mathrm{m}$. 


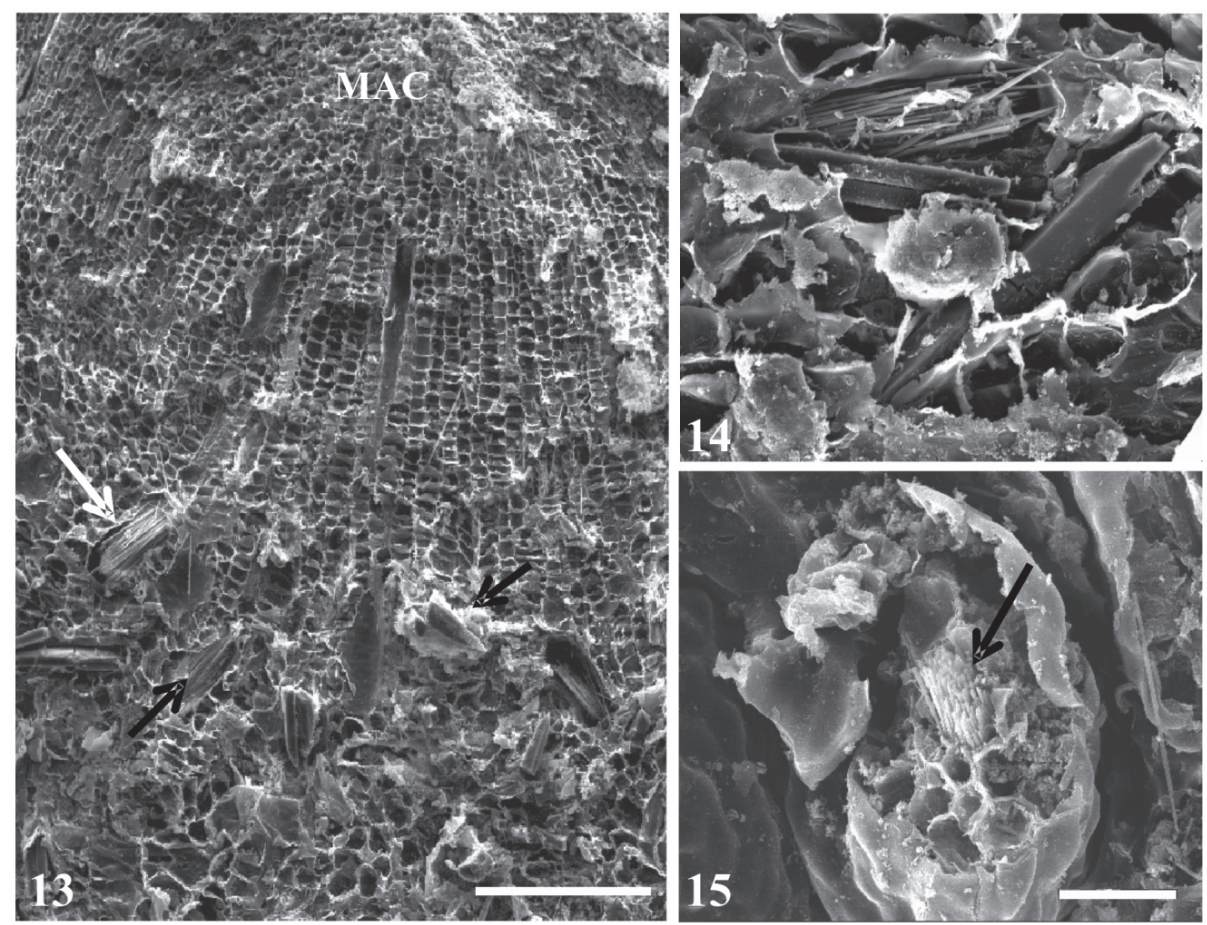

Figures 13-15. SEM of the stem apex and colleters of P. nuda. 13. Apical meristem (MAC) and surrounding regions, note the abundance of raphide bundles and styloid crystals; 14 . Close up of the raphide bundles and styloid crystals on a stipule. 15. Transversal section of a colleter showing the raphide bundles in the central axis (arrow). Bars: $13-500 \mu \mathrm{m} ; 14-50 \mu \mathrm{m} ; 15-100 \mu \mathrm{m}$.
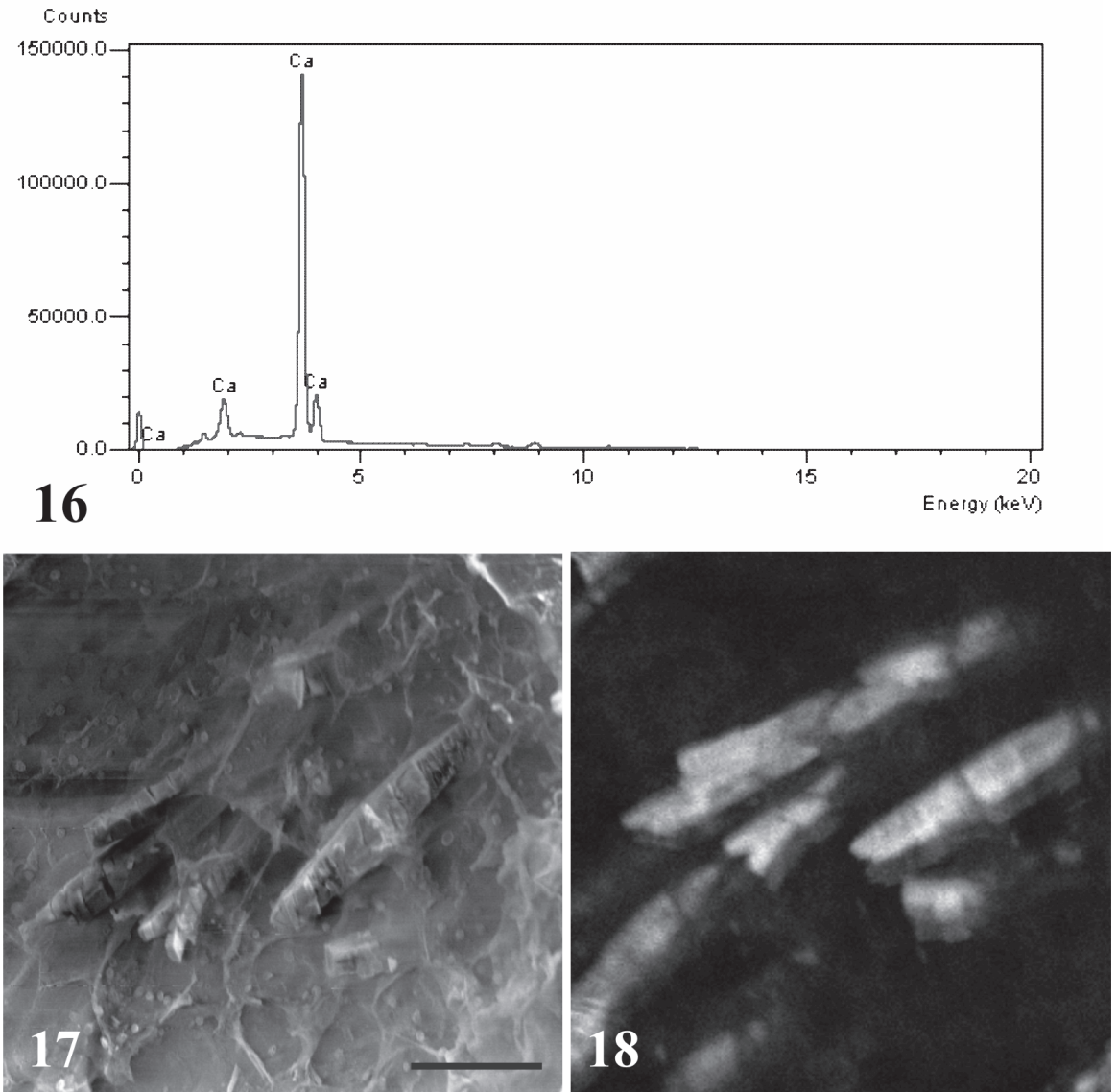

Figures 16-18. Microanalysis of an X-ray of the crystals of $P$. nuda. 16. Qualitative analysis of the constitution of the chemical elements of the crystals; 17 . Raphide bundles in a stipule (secondary electrons); 18. Speed Map® showing where calcium is present in the former image. Bars: 17 and $18-50 \mu \mathrm{m}$. 
Hanley et al. (2007) mentioned that the crystals are part of the structural defense of the plants. Ruiz et al. (2002) showed the distribution of calcium oxalate crystals in the leaf mesophyll of Pancratium sickenbergeri, and this work revealed that larvae avoid the parts of the leaf that contain these crystals.

More studies are needed to fully understand the function of the calcium crystals in the colleters of Psychotria nuda.

\section{Acknowledgements}

We thank the Coordenação de Aperfeiçoamento de Pessoal de Nível Superior (CAPES); Conselho Nacional de Desenvolvimento Científico e Tecnológico (CNPq) and Fundação de Amparo à Pesquisa do Rio de Janeiro (FAPERJ), for financial support; B.F. Ribeiro, and G.A. Moraes of the LBCT/CBB/UENF technicians. This study was part of the $\mathrm{PhD}$ thesis of the first author, presented to the Programa de Pós-Graduação em Biociências e Biotecnologia/UENF.

\section{References}

Appezzato-da-Gloria, B. \& Estelita, M.E.M. 2000. Development, structure and distribution of colleters in Mandevilla illustris and M. velutina (Apocynaceae). Revista Brasileira de Botânica 23: 113-120.

Barros, C.F. \& Miguens, F.C. 1998. Ultrastructure of the epidermal cell of Beilshmeidia rigida (Mez) Kosterm (Lauraceae). Acta Microscopica 7: 1-11.

Curtis, J.D. \& Lersten, N.R. 1974. Morphology, seasonal variation and function of resin glands on buds and leaves of Populus deltoides (Salicaceae). American Journal of Botany 61: 835-845.

Da Cunha, M. \& Vieira, R.C. 1993/97. Anatomia foliar de Psychotria velloziana Benth. (Rubiaceae). Rodriguésia 49: 39-50.

Da Cunha, M. 2005. Coléteres: Estruturas secretoras em Rubiaceae. In: Tópicos Atuais em Botânica. $55^{\circ}$ Congresso Nacional de Botânica, Curitiba.

Dave, Y. \& Patel, N.D. 1975. A developmental study of extrafloral nectaries in slipper spurge (Pedialanthus tithymaloides, Euphorbiaceae). American Journal of Botany 62: 808-812.

Dexheimer, J. \& Guenin, F.1981. Étude de la sécrétion de mucilage par le trichomes stipulaires de Psychotria bacteriophyla (Rubiaceae). Cytologia 46:731-747.

EMBRAPA. 1994. Vegetação das áreas de entorno do Jardim Botânico do Rio de Janeiro, Horto Florestal e Parque Lage 1 Rio de Janeiro: JBRJ/IBAMA. 69p.

Fahn, A., 1990. Plant Anatomy. Pergamon Press, Oxford. 558 p.

Franceschi, V.R. \& Nakata, P.A. 2005. Calcium oxalate in plants: Formation and function, Annual Review of Plant Biology 56: 41-71.

Gomes, D.M.S.; Montovani, A. \& Vieira, R.C. 1995. Anatomia foliar de Psychotria tenuinervis Muell. Arg. e Psychotria stenocalix Muell. Arg. (Rubiaceae). Arquivos de Biologia e Tecnologia 38:15-33.

González, A.M. 1998. Colleters in Turnera and Piriqueta (Turneraceae). Botanical Journal of the Linnean Society 128: 215-228.

Hanley, M.E.; Lamont, B.B.; Fairbanks, M.M. \& Rafferty C.M. 2007. Plant structural traits and their role in anti-herbivore defence. Perspectives in Plant Ecology, Evolution and Systematics 8: 157-178.

Horner, H. T \& Lersten, N. R. 1968. Development, structure and function of secretory trichomes in Psychotria bacteriophila (Rubiaceae). American Journal of Botany 55:1089-1099.
Hudgins, J.W. Krekling, T. \& Francheschi, V.R. 2003. Distribution of calcium oxalate crystals in the secondary phloem of conifers: a constitutive defence mechanism? New Phytologist 159: 677-690.

Johansen, D. 1940. Plant microtechnique. McGray-Hill Book Company. Inc. Nex York. 523p.

Klein, D.E.; Gomes, V.M.; Silva-Neto, S.J.; Da Cunha, M. 2004. The structure of colleters in several species of Simira (Rubiaceae). Annals of Botany 94: 733-740.

Korth, K.L.; Doege, S.J.; Park, S.H.; Goggin, F.L.; Wang, Q.; Gomez, S.K.; Liu, G.; Jia L. \& Nakata, P.A. 2006. Medicago truncatula mutants demonstrate the role of plant calcium oxalate crystals as an effective defence against chewing insects. Plant Physiology 141: 188-195.

Lersten, N.R. 1974a. Morphology and distribution of colleters and crystals in relation to the taxonomy and bacterial leaf nodules in Psychotria (Rubiaceae). American Journal of Botany 61: 973-981.

Lersten, N.R. 1974b. Colleter morphology in Pavetta, Neorosea and Tricalysia (Rubiaceae) and its relationship to the bacterial leaf nodule symbiosis. Botanical Journal of the Linnean Society 69: 125-136.

Lersten, N.R. 1975. Colleter types in Rubiaceae, especially in relation to the bacterial leaf nodule symbiosis. Botanical Journal of the Linnean Society 71: 311-319.

Metcalfe, C.R. \& Chalk, L. 1950. Anatomy of Dicotyledons. Oxford. Clarendon Press. 223p.

Miguel, E.C.; Gomes, V.M.; De Oliveira, M.A. \& Da Cunha, M. 2006. Colleters in Bathysa nicholsonii K. Schum. (Rubiaceae): Ultrastructure, secretion protein composition and antifungal activity. Plant Biology 8: 715-722.

Miller, I. M., Scott, A. \& Gardner, I. C. 1983. The development, structure and function of dendroid colleters in Psychotria kirkii (Rubiaceae). Annals of Botany 51:621-630.

Paiva E.A.S. \& Machado S.R. 2006b. Ontogênese, anatomia e ultraestrutura dos nectários extraflorais de Hymenaea stigonocarpa (Fabaceae, Caesalpinioideae). Acta Botanica Brasilica 20: 471-482.

Paiva, E.A.S. \& Machado, S.R. 2006a. Ontogenesis, structure and ultrastructure of Hymenaea stigonocarpa (Fabaceae : Caesalpinioideae) colleters. Revista de Biologia Tropical 54: 943-950.

Ramayya, N. \& Bahadur, B. 1968. Morphology of the "squamellae" in the light of their ontogeny. Current Science 37: 520-522.

Robbrecht, E., 1988. Tropical woody Rubiaceae. Characteristic features and progressions. Contributions to a new subfamilial classification. Opera Bot. Belg. Meise. 271 p.

Ruiz, N., Ward, D. \& Saltz, D. 2002. Calcium oxalate crystal in leaves of Pancratium sickenbergeri: constitutive or induced defence? Functional Ecology 16: 99-105.

Simões, A.O. Castro, M.D.M. \& Kinoshita, L.S. 2006. Calycine colleters of seven species of Apocynaceae (Apocynoideae) from Brazil. Botanical Journal of the Linnean Society 152: 387-398.

Thomas, V. 1991. Structural, functional and phylogenetic aspects of the colleter. Annals of Botany 68: 287-305.

Van Hove, C. \& Kagoyre, K. 1974. A comparative study of stipular glands in nodulating and non-nodulating species of Rubiaceae. Annals of Botany 38: 989-991.

Vieria, R.C. \& Gomes, D.M.S. 1995. Superfície da lâmina foliar de Psychotria nuda Cham. \& Schltdl. Wawra e P.leiocarpa Cham. \& Schltdl. P. stenocalyx Mull. Arg. e P. tenuinervis Mull. Arg. (Rubiaceae). Acta Botanica Brasilica 9:185-195.

Ward, D. Spiegel, M. \& Saltz, D. 1997. Gazelle herbivory and interpopulation differences in calcium oxalate content of leaves of a desert lily. Journal of Chemical Ecology 23: 333-346.

Whitmoyer, R.E. \& Horner, H.T. 1970. Developmental aspects of bacterial leaf nodules in Psychotria bacteriophila VAL. (Rubiaceae). Botanical Gazette 131: 193-200. 